International Journal of Current Advanced Research

ISSN: O: 2319-6475, ISSN: P: 2319 - 6505, Impact Factor: SJIF: 5.995

Available Online at www.journalijcar.org

Volume 6; Issue 5; May 2017; Page No. 3913-3915

DOI: http://dx.doi.org/10.24327/ijcar.2017.3915.0395

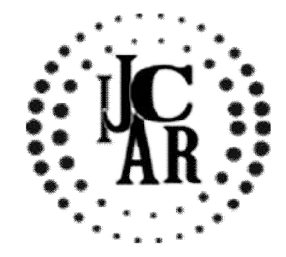

Research Article

\title{
POORLY DIFFERENTIATED LARGE CELL NEUROENDOCRINE CARCINOMA OF THE GALLBLADER
}

\section{Sinaa Mohamed ${ }^{\text {., }}$ Oukabli Mohamed ${ }^{2}$ and Albouzidi Abderrahmane ${ }^{2}$}

${ }^{1}$ Department of pathology, Military Hospital Moulay Ismail, Meknes, Morocco

${ }^{2}$ Department of pathology, Military Hospital Mohammed V, Rabat, Morocco

\section{A R T I C L E I N F O}

\section{Article History:}

Received $17^{\text {th }}$ February, 2017

Received in revised form $12^{\text {th }}$ March, 2017

Accepted $8^{\text {th }}$ April, 2017

Published online $28^{\text {th }}$ May, 2017

\section{Key words:}

Gallbladder, Poorly differentiated large cell endocrine carcinoma, surgery, prognosis.

\begin{abstract}
A B S T T R A C T
Introduction: Neuroendocrine tumors (NET) of the gallbladder are rare. Only $0.2 \%$ of all NET Of the digestive system are localized in the gallbladder. We report an exceptional case of poorly differentiated large cell neuroendocrine carcinoma of the gallbladder (LCNEC). Observation: A 54-year-old man, admitted for hepatic colic evolving for 16 months. The ultrasound and the scanner are objectived a vesicular multilithiasic. Cholecystectomy by celoscopy was performed. The pathological study concluded with poorly differentiated a large cell neuroendocrine carcinoma confirmed by the immunohistochemical study.

Discussion: With only eight cases reported in the literature, LCNEC of the gallbladder, part of the NET group, is exceptional. It is probably derived from cells of the diffus neuroendocrine system (DNES) in a context of chronic inflammation by vesicular lithiasis. The diagnosis of certainty is the pathological and immunohistochemical study. This tumor is often diagnosed fortuitously during cholecystectomy for vesicular lithiasis in the few cases described in the literature. The treatment is essentially surgical. The indication of adjuvant therapy is discussed according to the prognostic factors. The survival at 5 years is $8,3 \%$.

Conclusion: Our study give more importance of systematic histological examination of all cholecystectomy specimens. The pathological study remains the only way to confirm the diagnosis, to establish staging and to guide the therapeutic approach.
\end{abstract}

Copyright $₫ 2017$ Sinaa Mohamed et al. This is an open access article distributed under the Creative Commons Attribution License, which permits unrestricted use, distribution, and reproduction in any medium, provided the original work is properly cited.

\section{INTRODUCTION}

Endocrine tumors of the gall bladder are very rare, accounting for less than $1 \%$ of gallbladder tumors and $0.2 \%$ of endocrine tumors of the digestive tract $[1,2]$. The poorly differentiated LCNEC, well individualized in the 2010 WHO classification of NET [3,4], is exceptional in the gallbladder and extrahepatic biliary tract with only eight observations described in the literature [5].

\section{Case report}

A 54-year-old man, without notable antecedents, had pains in the right hypochondrium evolving for 16 months, without other associated sign. The biological analyse was normal. Ultrasound and abdominal scanner showed a multilithiasic gallbladder with irregular thickened wall [Figure 1]. Cholecystectomy was decided. The macroscopic examination found a gallbladder measuring $12 \times 6 \times 5 \mathrm{~cm}$. At the opening, the presence of multiple lithiasis was noted, the wall was irregularly thickened. The microscopic study showed a proliferation with architecture made of nests, traveled without

*Corresponding author: Sinaa Mohamed Department of pathology, Military Hospital Moulay Ismail, Meknes, Morocco glandular formations [Figure 2]. The tumor cells were large, with abundant eosinophilic cytoplasm, reduced nucleocytoplasmic ratio, and an irregular nucleus.

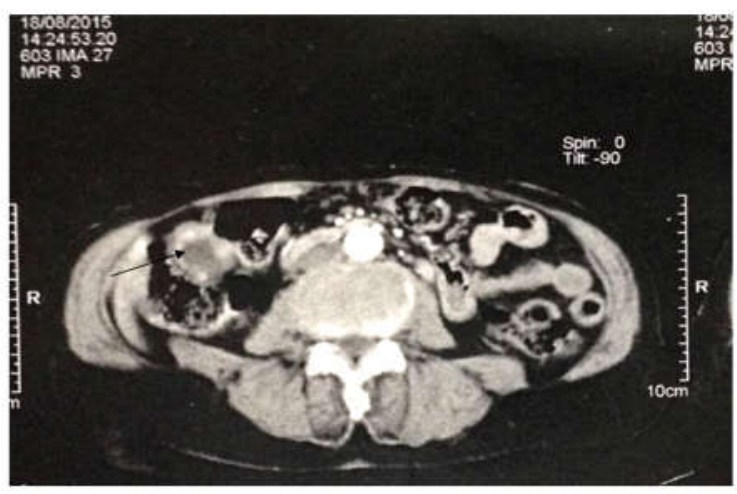

Figure 1 the scanner showing a multilithiasic galldblader ( $\mathbf{A})$

The nucleair had a granular chromatin [Figure 3]. The mitoses were estimated at 17 mitoses per ten fields at high magnification. The stroma is endocrinoid. The presence of large foyer of necrosis tumor was observed, without images of vascular embol. The Immunohistochemical complement showed a positivity of the tumors cells to chromogranin A 
[Figure 4] and synaptophysin [Figure 5]. The proliferativ index Ki67 was estimated about 40\% [Figure 6].

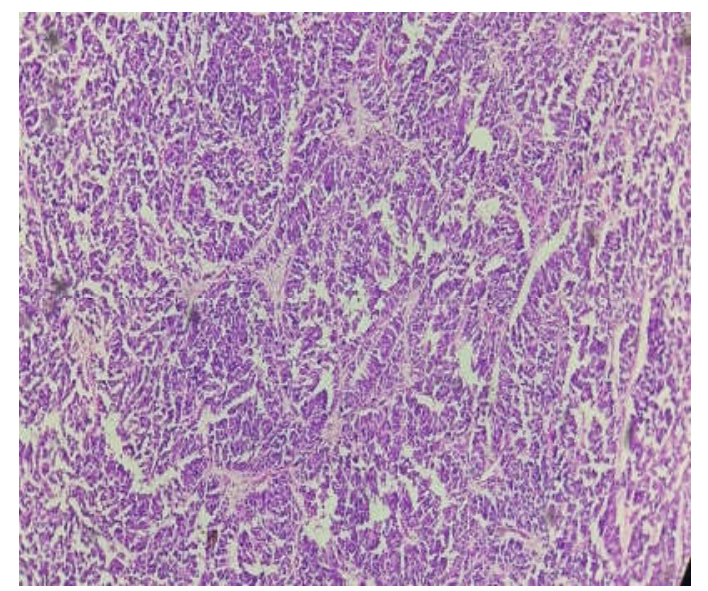

Figure 2 Pathologic findings : The tumor architecture made of nests, traveled without glandular formations $(\mathrm{H} \& \mathrm{E}, 200)$

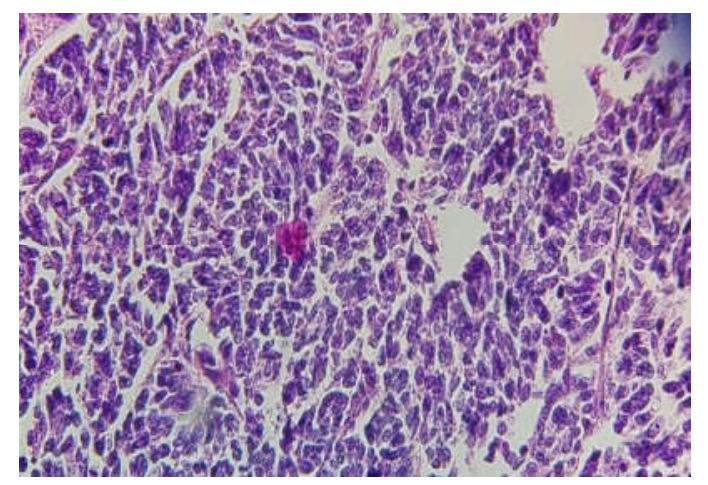

Figure 3 Pathologic findings : Large tumor cells, with an eosinophilic cytoplasm, a reduced nucleocytoplasmic raport, and an often eccentric nucleus. The nucleair had a granular chromatin (H\&E, 400)

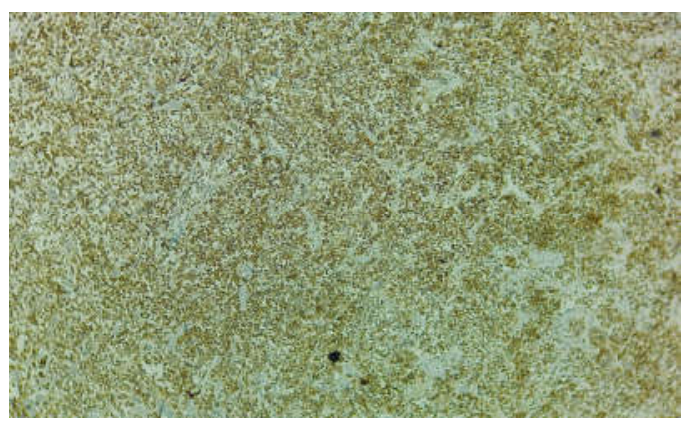

Figure 4 The tumor cells reveal immunopositivity for chromogranine A (x200)

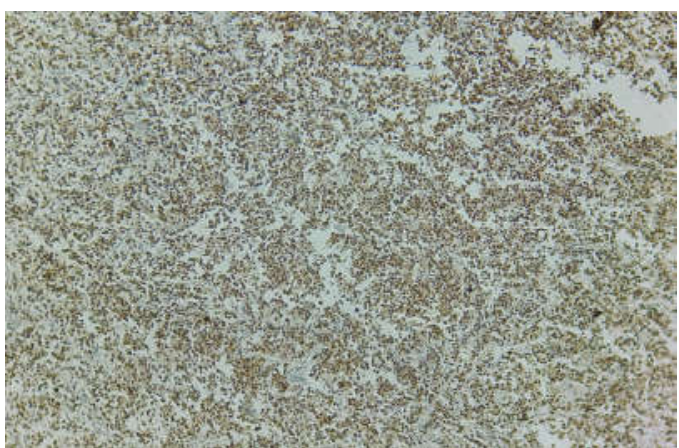

Figure 5 The tumor cells reveal immunopositivity for synaptophysine (x200)

The diagnosis of poorly differentiated neuroendocrine carcinoma with large cells of the gallbladder was retained.
The tumor infiltrated the muscularis. There was no evidence of ganglion at the vesicular collar. The section of surgical section was healthy. The tumor was classified T2N0.

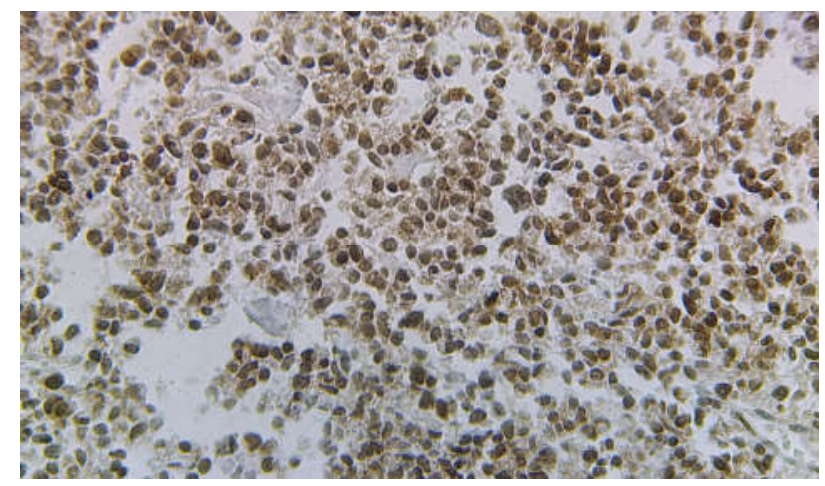

Figure 6 The $\mathrm{Ki} 67$ is estimated at $40 \%(\mathrm{x} 400)$

The Thoracic-Abdominal-Pelvic Magnetic resonance imaging was didn't show any other associated lesion.

The patient didn't receive any adjuvant treatment because the localized stage of the disease, the absence of lymph node, distal metastasis, or vascular embol. Clinical and radiological monitoring for 12 months didn't show any relapse or the occurrence of any secondary lesions.

\section{DISCUSSION}

In the gastrointestinal tract, neuroendocrine tumors (NET) are very rare and very heterogeneous, accounting for less than $7 \%$ of all digestive system tumors. The most frequent localizations are small intestin and appendix. The localisation in the gallbladder accounts for less than $1 \%$ of all NET in the digestive system. The WHO classification 2010 distinged three types of endocrine tumors: neuroendocrine tumors low grade-high grade, neuroendocrine carcinomas (small cell and large cell) and adeno-neuroendocrine carcinoma. The histopathological and immunohistochemical characteristics of these tumors are well defined despite their rarity $[2,6,7]$.

The tumor described in this observation meets the diagnostic criteria for poorly differentiated large cell neuroendocrine carcinoma as described in the 2010 classification of NET [4], a tumor architecture show a endocrine differentiation with a disposition of cells in nids, traveled, or palissades, without glandular formation. The cells are larg with a low nucleocytoplasmic ratio, granular chromatin, and a nucleir often nucleolated. The mitotic index is more than ten mitoses in ten fields at high magnification. Presence of areas of necrosis tumor. The major diagnostic critere is the expression of two markers of the three neuroendocrine markers: chromogranin A, synaptophysin and CD56. This tumor is easily distinguished from well differentiated large cells neuroendocrine carcinomas by a mitotic index more than ten mitoses in ten fields, by more pronounced cellular atypias and by extensive tumor necrosis $[8,9,10]$. Small cell carcinomas have the same characteristics as their large cell counterparts and are distinguished by the small cell size (smaller than the diameter of three lymphocytes), a high nucleocytoplasmic ratio, finely granular chromatin without nucleolus and frequent crushing artifacts $[1,2,4]$.

The histogenesis of LCNEC is controversial [11]. Disseminated endocrine cells of the DNES are present in the normal state in the biliary epithelium [8]. They are more 
numerous in a context of chronic inflammation by lithiasis [1, $8]$.

Clinically, like any neuroendocrine tumor, the gallbladder may be secreting or non-secreting [10]. The circonstances of the discovery of neuroendocrine tumors are extremely varied and may be related to the local effect of the tumor if the tumor is non-secreting: right hypochondrium pain, with a large gallbladder. They can be discovered on a piece of cholecystectomy for simple cholecystitis or after surgical treatment of a gallbladder suspected of malignancy. For secreting tumors, the symptoms vary depending on the nature of the secreted peptide $[7,11]$.

Due to the rarity of this tumor and the lack of knowledge of predictive factors for prognosis, there is no standard protocol for treatment. The latter is essentially surgical with surveillance for localized tumors. Chemotherapy combining cisplatin, etoposide and CPT-11 is indicated for advanced disease, metastatic lymph nodul or vascular embol. The place of radiotherapy is not known. The survival at 5 years is 8,3 $\%$.

\section{CONCLUSION}

We reported the ninth case of a poorly differentiated large cells neuroendocrine carcinoma of the gallbladder. The symptomatology is not specific. The pathological study remains the only way to make the diagnosis, to establish the histo-prognostic factors, and to orient the therapeutic approach. Our study draws attention to a very rare entity and the importance of histological examination of any cholecystectomy for diagnosis of this tumor at an early stage.

\section{Références}

1. Albores-Saavedra J, Henson DE, Angeles AA. Tumors of the Gall-bladder and Extrahepatic Bile Ducts. Atlas of Tumor Pathology. Third series. Washington, D.C.: AFIP; 2000.
2. Hamilton SR, Aaltonen LA, editors. World Health Organization Classification of Tumours: Pathology and Genetics of Tumours of the Digestive System. Lyon: IARC Press; 2000.

3. Yamamoto J, Abe Y, Nishihara K, Katsumoto F, Takeda S, Abe R, et al. Composite glandularneuroendocrine carcinoma of the hilar bile duct: report of a case. Surg Today 1998; 28: 758-62.

4. Travis WD, Brambilla E, Muller-Hermelink HK, Harris CC, edi-tors. World Health Organization Classification of Tumours: Pathology and Genetics of Tumours of the Lung, Pleura, Thy-mus, and Heart. Lyon: IARC Press; 2004.

5. Sato $\mathrm{K}$, Waseda $\mathrm{R}$, Tatsuzawa $\mathrm{Y}$, Fujinaga $\mathrm{H}$, Wakabayashi T, Ueda Y, et al. Composite large cell neuroendocrine carcinoma and adenocarcinoma of the common bile duct. J Clin Pathol 2006; 59:105-7.

6. Bernick PE, Klimstra DS, Shia J, Minsky B, Saltz L, Shi W, et al. Neuroendocrine carcinomas of the colon and rectum. Dis Colon Rectum 2004; 47:163-9.

7. Nassar H, Albores-Saavedra J, Klimstra DS. Highgrade neuroendocrine carcinoma of the ampulla of Vater. A clinico-pathologic and immunohistochemical analysis of 14 cases. $A m J$ Surg Pathol 2005; 29:588-94.

8. Rugge M, Sonego F, Militello C, Guido M, Ninfo V. Primary car-cinoid tumor of the cystic and common bile ducts. Am J Surg Pathol 1992; 16:802-7.

9. Hervieu V, Scoazec JY. Mixed endocrine tumors. Ann Pathol 2005; 25:511-28.

10. Montuenga LM, Guembe L, Burrell MA, Bodegas ME, Calvo A, Sola JJ, et al. The diffuse endocrine system: from embryogenesis to carcinogenesis. Prog Histochem Cytochem 2003; 38:155-272.

11. Faggiano A, Sabourin JC, Ducreux M, Lumbroso J, Duvillard P, Leboulleux S, et al. Pulmonary and extrapulmonary poorly dif-ferentiated large cell neuroendocrine carcinomas. Diagnostic and prognostic features. Cancer 2007; 110:265-74.

\section{How to cite this article:}

Sinaa Mohamed et al (2017) 'Poorly Differentiated Large Cell Neuroendocrine Carcinoma Of The Gallblader', International Journal of Current Advanced Research, 06(05), pp. 3913-3915.

DOI: http://dx.doi.org/10.24327/ijcar.2017.3915.0395 